Boston University School of Law

Scholarly Commons at Boston University School of Law

Faculty Scholarship

Fall 2021

\title{
Public Health and the Power to Exclude: Immigrant Expulsions at the Border
}

Sarah R. Sherman-Stokes

Boston University School of Law

Follow this and additional works at: https://scholarship.law.bu.edu/faculty_scholarship

Part of the Immigration Law Commons

\section{Recommended Citation}

Sarah R. Sherman-Stokes, Public Health and the Power to Exclude: Immigrant Expulsions at the Border, in 36 Georgetown Immigration Law Journal 261 (2021).

Available at: https://scholarship.law.bu.edu/faculty_scholarship/1141

This Article is brought to you for free and open access by Scholarly Commons at Boston University School of Law. It has been accepted for inclusion in Faculty Scholarship by an authorized administrator of Scholarly Commons at Boston University School of Law. For more information, please contact lawlessa@bu.edu. 


\section{HEINONLINE}

DATE DOWNLOADED: Wed Oct 5 22:19:08 2022

SOURCE: Content Downloaded from HeinOnline

Citations:

Bluebook 21st ed.

Sarah Sherman-Stokes, Public Health and the Power to Exclude: Immigrant Expulsions at the Border, 36 GEO. IMMIGR. L.J. 261 (2021).

ALWD 7th ed.

Sarah Sherman-Stokes, Public Health and the Power to Exclude: Immigrant Expulsions at the Border, 36 Geo. Immigr. L.J. 261 (2021).

APA 7th ed.

Sherman-Stokes, S. (2021). Public health and the power to exclude: immigrant

expulsions at the border. Georgetown Immigration Law Journal, 36(1), 261-290.

Chicago 17th ed.

Sarah Sherman-Stokes, "Public Health and the Power to Exclude: Immigrant Expulsions at the Border," Georgetown Immigration Law Journal 36, no. 1 (Fall 2021): 261-290

McGill Guide 9th ed.

Sarah Sherman-Stokes, "Public Health and the Power to Exclude: Immigrant Expulsions at the Border" (2021) 36:1 Geo Immigr LJ 261.

AGLC 4th ed.

Sarah Sherman-Stokes, 'Public Health and the Power to Exclude: Immigrant Expulsions at the Border' (2021) 36(1) Georgetown Immigration Law Journal 261

MLA 9th ed.

Sherman-Stokes, Sarah. "Public Health and the Power to Exclude: Immigrant Expulsions at the Border." Georgetown Immigration Law Journal, vol. 36, no. 1, Fall 2021, pp.

261-290. HeinOnline.

OSCOLA 4th ed.

Sarah Sherman-Stokes, 'Public Health and the Power to Exclude: Immigrant Expulsions at the Border' (2021) 36 Geo Immigr LJ 261

Provided by:

Fineman \& Pappas Law Libraries

-- Your use of this HeinOnline PDF indicates your acceptance of HeinOnline's Terms and Conditions of the license agreement available at https://heinonline.org/HOL/License

-- The search text of this PDF is generated from uncorrected OCR text.

-- To obtain permission to use this article beyond the scope of your license, please use: Copyright Information 


\title{
PUBLIC HEALTH AND THE POWER TO EXCLUDE: IMMIGRANT EXPULSIONS AT THE BORDER
}

\author{
SARAH SHERMAN-STOKES*
}

\begin{abstract}
We are presently in the midst of a crisis at the U.S.-Mexico border as courts and the Biden administration struggle to manage thousands of immigrants waiting to seek legal protection, typically asylum, in the midst of a global pandemic. Beginning in March of 2020, against the advice of public health experts, the U.S. government closed the southern U.S.-Mexico border, disproportionately impacting would-be asylum seekers from Central America, who are now immediately expelled from the United States under a process known as "Title 42" should they reach the border. Not only do these expulsions lack a legitimate public health rationale, but they also violate our domestic and international legal obligations to protect immigrants at risk of persecution or torture.

This Article begins by exploring the historic intersections of public health and immigration law and the origins of federal quarantine and exclusion power. Woven into the Article are first-hand accounts of advocates on both sides of the border who have witnessed the devastating impact of COVID-19 era immigrant expulsions. Ultimately, this Article argues that we must seek alternatives - including ending Title 42 expulsions, deferring to public health experts, dispatching additional resources to the border and ending our reliance on immigration detention.
\end{abstract}

TABLE OF CONTENTS

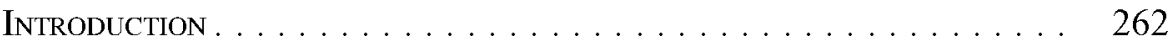

\footnotetext{
* Associate Clinical Professor of Law, Boston University School of Law. Thank you to Sabi Ardalan, Kate Evans, Lindsay Harris, and Laila Hlass for thoughtful feedback, as well as to members of the 2020 NYU Clinical Law Review Writer's Workshop. Thanks also goes to Boston University School of Law, and Dean Onwuachi-Willig, for summer research grant support for this project. To the tenacious advocates on the ground, along the southwest border, thank you for taking the time to graciously speak with me about your work, and the experiences of your clients. Finally, special thanks to research assistants Anyela Perez and Maggie Lovric for their careful edits and excellent research. All errors are my own. (C) 2021, Sarah Sherman-Stokes.
} 
I. Public Health and Immigration Law . . . . . . . . . . . . . . 267

A. Health Based Exclusions . . . . . . . . . . . . . . . . 267

B. Origin of Federal Quarantine Power . . . . . . . . . . 270

C. Application of Federal Quarantine Power during COVID-

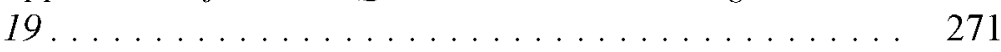

II. Snapshots From Both Sides of the Border . . . . . . . . . . . . 272

A. "Central American Asylum Seekers Are Rendered Invisible By Title 42.”. . . . . . . . . . . . . . . . . . . . . . . 274

B. "There Is No Asylum Anymore." . . . . . . . . . . . . . . 276

C. "There Has Always Been Worry, But Now There Is Despair." . . . . . . . . . . . . . . . . . . 278

D. "IfThey Stay, They Can Be Killed. If They Flee, They Can Be Killed.". . . . . . . . . . . . . . . . . . . . . 279

III. The Legacy of Racism Directed Toward Central American RefugeEs . . . . . . . . . . . . . . . . . . . . . 280

IV. Title 42 Alternatives . . . . . . . . . . . . . . . . . . . . 284

A. Title 42 Violates Our Domestic and International Legal Obligations........................ 285

B. We Must Heed the Advice of Public Health Experts . . . . . 286

C. Dispatch Additional Resources to the Border to Process Migrants Quickly...................... 286

D. End Reliance on Detention and Congregate Settings and Promote Family Unity . . . . . . . . . . . . . . . . . . . . . . 287

Conclusion . . . . . . . . . . . . . . . . . . . . . . . . 289

\section{INTRODUCTION}

Quarantine power, coupled with legacies of xenophobia, racism and a historic distrust of noncitizens and the public health threats they allegedly bring to our shores, means that in the wake of a public health crisis, the U.S. government often acts swiftly to exclude foreigners. The COVID-19 pandemic has been no exception. Beginning in March of 2020, the U.S. government closed the southern U.S.-Mexico border against the advice of public health experts, disproportionately impacting would-be asylum seekers from Central 
America, who are now immediately expelled from the United States should they reach the border. Not only do these expulsions lack a public health rationale but they also violate our domestic and international legal obligations to protect immigrants at risk of persecution or torture and contribute to a long legacy of racism specifically directed at would-be asylum seekers from Central America.

During a November 2019 meeting on Central American asylum seekers, Senior Advisor to then-President Trump and anti-immigrant zealot Stephen Miller remarked that ending migration from Central America is "[a]ll I care about." " Miller is just the latest in a long line of U.S. government officials expressing anti-Central American sentiment. This sentiment is pervasive and drives a racist and xenophobic immigration policy that has conspired to keep Central Americans out of the United States. For at least forty years, since the creation of the Refugee Act of 1980, Central American refugees have faced special animus and discrimination when claiming both admission to the United States, and protection once here. ${ }^{2}$ Systemic evidence of bias against asylum seekers from Central America was revealed in a lawsuit by the American Civil Liberties Union ("ACLU") in $1982^{3}$ and has continued to the present day. ${ }^{4}$ This Article amplifies the voices of advocates on the ground along the southwest border to help contextualize the latest example of antiCentral American refugee policy-a COVID-19 related asylum ban masquerading as a public health protection. To date, the Biden administration, despite campaign promises, has doubled down, continuing to argue erroneously that public health requires an asylum ban at the border. ${ }^{5}$ This Article intends to show why this rationale is misguided, and where and why there is the potential for real and meaningful progress.

This Article builds upon the scholarship of others who have written at the intersections of both health and immigration law and the racist explanations used to justify myriad barriers to immigration. ${ }^{6}$ Of course, the two are

1. Jonathan Blitzer, How Stephen Miller Manipulates Donald Trump to Further His Immigration Obsession, NEw YORKER (Feb. 21, 2020), https://perma.cc/VH64-6JLV.

2. Sarah Sherman-Stokes, Reparations for Central American Refugees, 96 DENVER L. REV. 585, 590 (2019).

3. Orantes-Hernandez v. Smith, 541 F. Supp. 351, 374 (C.D. Cal. 1982) (issuing a preliminary injunction and finding that the then-Immigration and Naturalization Service ("INS") had violated the rights of Salvadoran asylum seekers by denying them access to counsel, forcing them to sign voluntary departure orders, and placing them in solitary confinement).

4. As does systemic discrimination against many other groups of refugees, disproportionately Black immigrants and immigrants of color. See, e.g., Alan M. Kraut, Silent Travelers: Germs, Genes, AND THE "IMMIGRANT MENACE" 260-61 (1994) (describing the discriminatory treatment of Haitian immigrants during the AIDS crisis); Haitian Centers Council, Inc. v. Sale, 823 F. Supp. 1028, 1049-50 (E.D.N. Y. 1993) (granting admission to 158 Haitian refugees that had been detained at the U.S. Naval Base at Guantanamo Bay for more than two years simply because they had tested positive for HIV).

5. Sabrina Rodriguez, Biden Administration Renews Title 42 Order, as ACLU Fights Back, POLITICO (Aug. 2, 2021, 7:49 PM), https://perma.cc/M9XF-5ZW9.

6. Including everything from the alcohol related prohibitions on immigration rooted in racism and classism, to present day proposals that would target suspected gang members, who are almost exclusively Central American. See Jayesh M. Rathod, Distilling Americans: The Legacy of Prohibition on U.S. Immigration Law, 51 Hous. L. REv. 781 (2014); Press Release, Dep't of Justice, Dep'ts of Justice and 
intimately connected, as public health and health-based immigrant exclusions have long been proxies for discriminatory immigration policies. This piece also expands on my own article, Reparations for Central American Refugees, which argued that, given the long history of racism and discrimination directed at Central American refugees, the only adequate means of reparation is federal legislation carving out special, tailored protections for this group.

This piece will examine the latest manifestation of Central American asylum discrimination: border closure policies thinly veiled as legitimate public health responses. As of March 2020, noncitizens are being denied entry at both the U.S. northern and southern borders in response to the global coronavirus pandemic. ${ }^{7}$ This order was subsequently extended indefinitely in May $2020^{8}$ and re-issued in October 2020. ${ }^{9}$ While noncitizens from 146 different countries were apprehended along the southern border in FY 2019, migrants and asylum seekers from El Salvador, Guatemala and Honduras made up over seventy percent of those apprehended in that group. ${ }^{10}$ Border closure policies disproportionately impact these noncitizens. Therefore, this Article focuses on this population.

The Trump administration's stated justification for suspending entry of noncitizens to the United States was an effort to control the COVID-19 pandemic. In August 2021, the Biden administration issued an updated order, continuing to argue that the ongoing pandemic provides a public health justification. Most troubling, the order can remain in place indefinitely. In court filings, the Biden administration has argued that lifting the Title 42 asylum ban at the border would, "exacerbate overcrowding at DHS facilities and create significant public health risks." By drawing on qualitative interviews with

Homeland Sec. Publish Final Rule to Restrict Certain Criminal Aliens' Eligibility for Asylum (Oct. 20, 2020), https://perma.cc/28D6-HTUM; see also Polly J. Price, Tuberculosis Control Laws in the U.S. Mexico Border Region: Legal Framework in the United States 7-8 (Emory Univ. Sch. of L. Legal Stud. Rsch. Paper, Paper No. 15-371, 2015), https://perma.cc/AYL5-CNSZ; Michelle A. Daubert, Comment, Pandemic Fears and Contemporary Quarantine: Protecting Liberty Through a Continuum of Due Process Rights, 54 Buff. L. Rev. 1299, 1301-02 (2007); Judith Walzer LeavitT, Typhoid Mary: Captive to the Public's Health (1996) (This book documents the case of Mary Mallon, "typhoid Mary," who was twice isolated against her will, for a total of 26 years, without a trial. Historians point to her status as an Irish immigrant as a defining factor in her extensive isolation).

7. Migrants and asylum seekers from across the world flee violence and persecution and enter, or attempt to enter, the United States through its southern border. These people unquestionably confront horrific racism and discrimination as they attempt to seek refuge in the United States. This piece, however, will focus on Central Americans for reasons outlined herein. This piece argues that Central American immigrants are disproportionately targets of this administration's racism, discrimination and animus.

8. Notice of Order Under Sections 362 and 365 of the Public Health Service Act Suspending Introduction of Certain Persons from Countries Where a Communicable Disease Exists, 85 Fed. Reg. 17,060 (Mar. 20, 2020); Order Suspending Introduction of Persons from a Country Where a Communicable Disease Exists, 85 Fed. Reg. 16,567 (Mar. 20, 2020) (to be codified at 42 C.F.R.pt. 71).

9. Order Suspending the Right to Introduce Certain Persons from Countries Where a Quarantinable Communicable Disease Exists, 85 Fed. Reg. 65,806 (Oct. 13, 2020) (extending the March 20, 2020 order of the same name).

10. Total Apprehensions for FY19 through September 302019 by Sector and Citizenship (Oct. Ist through Sept. 30, 2019), U.S. CUSTOMS \& BORdER PROT. (Jan. 30, 2020), https://perma.cc/9H5B-MDTR (showing that 607,774 of those apprehended in FY 2019 were from Guatemala, El Salvador or Honduras, accounting for over seventy percent of total apprehensions at the southwest border that year). 
advocates on both sides of the border, this Article will illuminate the pretextual nature of the border closure, as well as the racial animus underlying this policy and, ultimately, why it violates U.S. law. This Article will also situate this discrimination-which specifically targets Central American asylum seekers, including children, for rapid expulsion—within the history of a U.S. immigration policy that consistently medicalizes racism and xenophobia under the guise of protecting public health.

How is the administration justifying summarily removing noncitizens, and Central Americans in particular, in the name of public health? Under the purported authority of the Public Health Service Act, ${ }^{11}$ the U.S. government has established new agency processes-including through a new regulation, the Centers for Disease Control and Prevention's ("CDC") March 2020 "Order Suspending Introduction of Certain Persons from Countries Where a Communicable Disease Exists." 12 These new regulations, along with other orders, memos, and sub-regulatory guidance, substantially restrict entry to noncitizens along the northern and southern borders. This Article will show that through what I refer to as the "Title 42 Process" the administration continues to reserve special animus for Central Americans seeking protection in the United States. Indeed, these processes and orders build on a long line of policies that discriminate against Central American refugees in particular. This Article takes the CDC order as a case study of racist, pretextual asylum restrictions to illuminate how this administration conflates public health with migration to target and exclude primarily Central American immigrants from meaningful access to due process and immigration relief. These policies, taken together, are, as Lucas Guttentag writes, a "choreographed exercise in result-driven line-drawing"13 - line-drawing with very real, and often devastating, consequences. Namely, these targeted efforts systematically deny Central Americans access to protections they are entitled to by domestic and international law, and which many need to survive.

Part I of this Article documents the historic entanglement of immigration and public health law with a focus on the Title 42 Process, including the CDC's "Regulations to Control Communicable Diseases" now being used to effectively end asylum at the southern border. Part II relies on qualitative interviews with immigration advocates and attorneys on the front lines on both sides of the southwest border to document the catastrophic impact of this order on asylum seekers. These interviews reveal how the Title 42 process endangers and disappears asylum seekers and has a disproportionate impact on Central American asylum seekers. Part III situates the Title 42 targeting of Central Americans within historic racism and discrimination faced

11. 42 U.S.C. $\$ \$ 265,268$ (1944).

12. Order Suspending Introduction of Persons from a Country Where a Communicable Disease Exists, 85 Fed. Reg. 16,567 (Mar. 20, 2020) (to be codified at 42 C.F.R. pt. 71).

13. Lucas Guttentag, Coronavirus Border Expulsions: CDC's Assault on Asylum Seekers and Unaccompanied Minors, JUST SECURITY (Apr. 13, 2020), https://perma.cc/JFA2-WESQ. 
by Central American asylum seekers for decades, as well as how this continued racism and discrimination manifest in today's asylum laws and policies. These laws and policies target Central American asylum seekers with almost unparalleled precision and animus. Finally, Part IV of this Article argues that the Title 42 Process should be rescinded in favor of alternate protocols that walk the line of both protecting public health and the legal right of immigrants to seek asylum in the United States.

\section{A Note on the Current Moment}

As this Article is being written, the world is suffering the effects of a historic global pandemic. COVID-19 is a pandemic infection caused by the novel coronavirus, SARS-CoV-2. ${ }^{14}$ In the United States, there have been well over 39 million confirmed COVID-19 infections, resulting in over 640,000 deaths. ${ }^{15}$ Worldwide, there have been over 215 million confirmed cases, resulting in more than 4.5 million deaths. ${ }^{16}$ Indeed, cases have been confirmed in at least 188 different countries and territories worldwide. ${ }^{17}$

The United States has responded to the global pandemic by instituting several travel bans of dubious efficacy. For example, in March 2020, the United States closed its northern and southern borders to nonessential travel - the first time such action has been taken. ${ }^{18}$ In the fall of 2020 , it emerged that then-Vice President Mike Pence ordered the border closure over the objection of the top doctor at the CDC who had previously "refused to comply with a Trump administration directive" to close the border, "saying there was no valid public health reason to issue it." ${ }^{19}$ Indeed, public health experts have weighed in, arguing that such an order is based on "specious justifications" that "fail[] to protect public health., ${ }^{\text {"20 }}$ Notably, the order focuses on noncitizens who lack documentation and arrive by land while exempting U.S. permanent residents, U.S. citizens, and tourists arriving by plane or shipeven though these modes of transportation are explicitly listed by the Department of Health and Human Services ("HHS") as "congregate settings with higher risk of disease transmission than land travel."21 The result of this order is transparently political; it will disproportionately impact, and has

14. Cassandra L. Atzrodt, Insha Maknojia, Robert D. P. McCarthy, Tiara M. Oldfield, Jonathan Po, Kenny T. L. Ta, Hannah E. Stepp \& Thomas P. Clements, A Guide to COVID-19: A Global Pandemic Caused by the Novel Coronavirus SARS-CoV-2, 287 FEBS J. 3633, 3634 (2020).

15. COVID Data Tracker, CTRS. FOR DiSEASE CONTROL AND PREVENTION, https://perma.cc/4MMG$4 \mathrm{G} 35$.

16. WHO Coronavirus Disease (COVID-19) Dashboard, WORLd Health ORG., https://perma.cc/ N6G8-DVC3.

17. Coronavirus: Which Countries Have Confirmed Cases?, AL JAZEERA (Sept. 20, 2020), https:// perma.cc/DNP6-PGVS.

18. Fact Sheet: DHS Measures on the Border to Limit the Further Spread of Coronavirus, DEP'T OF HoMELAND SEC. (Mar. 23, 2020), https://perma.cc/2WVF-SMHQ.

19. Jason Dearen \& Garance Burke, Pence Ordered Borders Closed After CDC Experts Refused, AP NEws (Oct. 3, 2020), https://perma.cc/84Z6-WDAD.

20. Letter from Joe Amon et al. to Alex Azar, Sec'y, Dep't of Health and Human Serv. \& Robert R. Redfield, Dir., Ctrs. for Disease Control and Prevention (May 18, 2020), https://perma.cc/SM3C-9CTA.

21. Id. 
disproportionately impacted, noncitizens traveling by foot over land from Central America, where murder rates are some of the highest in the world, and from where many children and families are fleeing severe and unrelenting persecution..$^{22}$

\section{Public Health and Immigration Law}

\section{A. Health Based Exclusions}

Professor Alan M. Kraut describes the longstanding intersections of public health and migration as a "double helix of health and fear of the foreignborn." ${ }^{.23}$ Indeed, for well over a century, physical and mental health-based grounds of inadmissibility in U.S. immigration law have been used as a proxy for excluding noncitizens the government deems undesirable. ${ }^{24}$ The grounds of inadmissibility, now codified at Section 212 of the Immigration and Nationality Act ("INA"), spell out categories of noncitizens who may be denied admission to the United States despite satisfying the criteria for an immigrant or nonimmigrant preference category or classification. ${ }^{25}$ These grounds of inadmissibility apply only to noncitizens who are seeking admission to the United States, usually at a port of entry or when seeking some kind of change of status. ${ }^{26}$

"Fear of contamination" by noncitizens has animated United States immigration law since the opening of Ellis Island in the late 19th century. ${ }^{27}$ These fears have dressed up nativism and xenophobia into justifiable concerns about public health risks - the response to which has been to almost categorically exclude certain groups of noncitizens from entry into the United States. ${ }^{28}$

As early as 1855, Representative Wentworth of Massachusetts introduced a bill to prevent the admission of "criminals, idiots, lunatics and insane and blind persons." ${ }^{29}$ By 1882, one of the "driving forces" informing U.S. immigration law was the exclusion of people with mental and physical defects. ${ }^{30}$

22. The murder rate is the number of murders per 100,000 people. According to the U.N., the ten countries with the highest homicide rates were: 1. El Salvador $(61.80)$, 2. Jamaica (57), 3. Honduras (41.7), . . . 9. Guatemala (26.1), 10. Dominica (25.7). See Murder Rate by Country 2020, WORLD Population Review, https://perma.cc/ET4Y-J9KP; U.N. OfF. ON DRUGS AND CRIME, Global STUdY on Homicide: Homicide Trends, Patterns and Criminal Justice Response 17 fig.4 (2019), https:// perma.cc/S9DT-BASX (listing the countries with highest homicide rates in 2017); Seth Robbins, 3 Crime Factors Driving Northern Triangle Migrants Out, INSIGHT CRIME (Oct. 30, 2018), https://perma.cc/ 4MJ7-V9L9.

23. Kraut, supra note 4, at 256.

24. Id. at $2-3$.

25. Immigration and Nationality Act (INA) § 212, 8 U.S.C. $§ 1182$.

26. Id. \$212(a)(1)(A)(ii).

27. See Kraut, supra note 4 , at $2-3$.

28. See id. at 5-6.

29. William Paul Dillingham, U.S. Immigr. Comm'n, Immigration Legislation, S. Doc. No. 61-758, at 15 (3d Sess. 1911) [hereinafter Senate Reports of the Immigration Commission] (noting that the bill was ultimately voted down).

30. Douglas C. Baynton, Defectives in the Land: Disability and American Immigration Policy, 18821924, 24 J. AM. ETHNIC HIST. 31, 32 (2005). A state-based proposal excluding noncitizens who were "criminals, idiots, lunatics, and insane and blind persons" was made by Massachusetts representative 
Just a few years later, with the Immigration Act of 1891, health-based exclusions became an integral part of U.S. immigration law. ${ }^{31}$ As the Bubonic Plague spread throughout the world via shipping routes in the mid 19th century, the United States became increasingly fearful of global pandemics that might reach U.S. shores. The 1891 Immigration Act named "persons suffering from a loathsome or a dangerous contagious disease" as a basis for exclusion and required a medical inspection for all noncitizens entering the United States at a port of entry. ${ }^{32}$ The 1917 "Book of Instructions for the Medical Inspection of Immigrants" included more than two dozen diseases that would result in the "mandatory exclusion" of noncitizens, including "idiots, imbeciles, epileptics, insane persons, persons afflicted with tuberculosis in any form, ringworm of the scalp and nails, leprosy, syphilis," and a handful of diseases caused by animal parasites, among others. Seven additional health related inadmissibility grounds were added by the Nationality Act of 1952, including the exclusion of any noncitizen "afflicted with tuberculosis in any form, or with leprosy, or any dangerous contagious disease."33

As Polly Price and others have documented, ${ }^{34}$ beginning in the early twentieth century, the U.S. Public Health Service screened all arriving noncitizens for physical and mental illness and contagious diseases, and for the physical ability to work and support themselves. ${ }^{35}$ In addition to exclusion based on health grounds, noncitizens could also be excluded if due to a medical condition or poverty, they were deemed likely to "become a public charge." ${ }^{36}$ Such "public charge" based exclusion, though outside the scope of this paper, continues in expanded form today. ${ }^{37}$

The addition of health-related grounds for inadmissibility in 1952 was not the end of health-based exclusions. ${ }^{38}$ Most pertinent to this discussion, the

Wentworth as early as 1855 . While this particular proposal failed to pass, it created a blueprint for federal policy to come. See Senate Reports of the Immigration Commission, supra note 29, at 15.

31. Immigration Act of 1891, Pub. L. No. 51-551, 26 Stat. 1084 (1891).

32. Pub. L. No. 51-551, §1, 26 Stat. 1084, 1084.

33. Immigration and Nationality Act of 1952, Pub. L. No. 414, § 212(a)(6), 66 Stat. 163, 182.

34. See Polly J. Price, Sovereignty, Citizenship, and Public Health in the United States, 17 N.Y.U.J. LeGis. AND Pub. Pol'y, 919, 931 (2014); see also AMY L. FAIRCHILd, SCIENCE AT THE BORders:

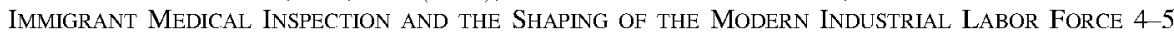
(2003) (exploring the intent of medical inspections).

35. See, e.g., U.S. Public Health and Marine-Hospital Service, Annual Report of the Surgeon General of the Public Health and Marine-Hospital Service of the United States 197-98 (1911); see also Fitzhugh Mulian, Plagues and Politics $40-48,92$ (1989).

36. See Fairchild, supra note 34 at 4-5; see also Public Charge Fact Sheet, U.S. CITIZENSHIP AND IMMIGR. SERVS., https://perma.cc/BR4Z-L9Y8.

37. 8 U.S.C. $\$ 1182(\mathrm{a})(4)($ A); Procedures for Asylum and Withholding of Removal; Credible Fear and Reasonable Fear Review, 85 Fed. Reg. 36,264 (proposed June 15, 2020) (to be codified at 8 C.F.R. pt. 208, 235, 1003, 1208, 1235); see also Martha Tepepa, Public Charge in the Time of Coronavirus (Levy Econ. Inst., Working Paper No. 950, 2020); Kathleen R. Page, Maya Venkataramani, Chris Beyrer \& Sarah Polk, Undocumented U.S. Immigrants and Covid-19, NEw ENG. J. MED (2020). But see Exec. Order 14012, Restoring Faith in Our Legal Immigration Systems and Strengthening Integration and Inclusion Efforts for New Americans, 86 Fed. Reg. 8,277 (Feb. 2, 2021).

38. For example, in 1996, the Illegal Immigration Reform and Immigrant Responsibility Act of 1996 ("IIRIRA") amended the INA to require prospective immigrants to demonstrate that they have been vaccinated against certain "vaccine-preventable" diseases. INA § 341; RUTH ELLEN WASEM, CONG. RSCH. 
1980s and 1990s brought the AIDS epidemic, and with it, continued racism and xenophobia and additional justifications for barring groups of noncitizens. Over Easter weekend in 1992, 140 Haitian refugees were denied admission to the United States after testing positive for HIV and held at Guantanamo Bay in "prison-like" conditions, until a federal judge intervened more than a year later. ${ }^{39}$ Prior to this, the Haitian immigrant community within the United States was quickly becoming one scapegoat for the nation's AIDS epidemic-despite the CDC debunking any connection between nationality and spread of the virus. ${ }^{40}$ Still, it was not until 2010 that thenPresident Obama finally removed HIV infection from the INA as a ground of inadmissibility. ${ }^{41}$

Today, all applicants for admission who have "a communicable disease of public health significance" are inadmissible under federal immigration law. ${ }^{42}$ At present, those diseases - a list of which is maintained by HHS-include: Gonorrhea; Hansen's Disease (Leprosy); Syphilis, infectious stage; and Tuberculosis ("TB"), Active. ${ }^{43}$ In addition, applicants for admission who "have a physical or mental disorder and [harmful] behavior associated with [those disorders]" are also inadmissible. ${ }^{44}$ While it is difficult to determine exactly how many noncitizens have been deemed inadmissible on medical and mental health grounds, they number at least in the hundreds, if not thousands, annually. ${ }^{45}$ But as of March 2020 , these health based exclusions are not the only basis for excluding noncitizens who seek admission to the United States. Federal quarantine power, ${ }^{46}$ interpreted for the first time by the Trump administration as the power to exclude and expel, ${ }^{47}$ is now the law of the land.

Serv., R40570, Immigration Policies and Issues on Health-Related Grounds for Exclusion (2014)).

39. Kraut, supra note 4, at 2; Haitian Centers Council, Inc. v. Sale, 823 F. Supp. 1028, 1042, 1049 50 (E.D.N.Y. 1993).

40. In April 1985, then Director of the CDC, Dr. Walter Dowdle admitted, "[t $t$ he Haitians were the only risk group that were identified because of who they were rather than what they did." Kraut, supra note 4 at 261; see also Haitians Removed from AIDS Risk List, N.Y. TIMES (Apr. 10, 1985), https://perma. cc/39ZB-U67K.

41. 42 C.F.R. § 34; see also Final Rule: Medical Examination of Aliens - Removal of HIV Infection from Definition of "Communicable Disease of Public Health Significance," CTRS. FOR DISEASE CONTROL And Prevention, https://perma.cc/Z72C-6ZUP.

42. INA \& $212(\mathrm{a})(1)(\mathrm{A})(\mathrm{i})$.

43. 42 C.F.R. $\$ 34.2(\mathrm{~b})$.

44. INA $\$ 212(\mathrm{a})(2)(\mathrm{A})(\mathrm{iii})$.

45. While ICE does not publish statistics on health-based exclusion of non-citizens, the U.S State Department does record health-based denials of immigrant and nonimmigrant visas. In 2019, the most recent year for which this data is available, more than 900 immigrants were found to be inadmissible to the United States due to communicable disease or lack of vaccinations. See FY 2019 Immigrant and Nonimmigrant Visa Ineligibilities (by Grounds for Refusal Under the Immigration and Nationality Act), U.S. DEP'T OF STATE (2019), hitps://perma.cc/7HL9-ESEE.

46. See 42 U.S.C. $\$ 265$.

47. See Def.'s Combined Opp'n to Pl.'s Mots. for Class Certification and for Classwide Prelim. Inj. at 3, P.J.E.S. v. Wolf, 502 F. Supp. 3d 492 (D.D.C. 2020) (No. 1:20-cv-02245-EGS). 


\section{B. Origin of Federal Quarantine Power}

Yellow Fever outbreaks in the 19th century largely drove the initial development of what we understand to be U.S. quarantine law. ${ }^{48}$ Immigration fears were also at play, as many blamed French refugees from Haiti for transmitting the illness in hard-hit Philadelphia, ${ }^{49}$ ultimately leading to state and then federal quarantine laws. Polly Price has traced the connections of both those developments to modern immigration law. ${ }^{50}$ In short, state health inspectors played the initial role in determining which noncitizens would be excluded as fear of a Yellow Fever pandemic spread in the nineteenth century. In an effort to stem the economic impact and protect the United States from the spread of contagious diseases, Congress got involved in the $1870 \mathrm{~s}$, seeking to expand the control and authority of the federal government over immigrant exclusion on the basis of public health. In 1878, a National Board of Health was created to monitor contagious disease at the federal level. While the Board was short lived, it laid the groundwork for future federal power in this arena. ${ }^{51}$

Later, in 1912, a National Health Board was created and subsequently, in 1944 the Regulations to Control Communicable Diseases" "clearly established the federal government's quarantine authority for the first time." ${ }^{53}$ The act gave the U.S. Public Health Service, a division of HHS, responsibility for "preventing the introduction, transmission, and spread of communicable diseases from foreign countries into the United States."

It is this act, establishing the federal government's quarantine authority, that is today being used to exclude noncitizens in the midst of the COVID-19 pandemic. But the way the federal quarantine power was born-and developed-is itself important. Quarantine power, coupled with a historic distrust of noncitizens and the public health threat they supposedly bring to the native-born, yields only one logical, though historically unfounded, conclusion: in the wake of a public health crisis, we must exclude foreigners to protect ourselves.

Today's order, the quarantine mandate that effectively seals the border and denies entry to thousands of noncitizens, including many refugees and asylum seekers, has a disparate and devastating impact: it has fallen predominantly on the backs of Central American, African, and Haitian asylum seekers, who will now be unable to seek protection in the United States-protection that they are legally entitled to seek.

48. Price, supra note 34, at 935 ("The modern division of quarantine authority among federal, state, and local governments can be traced historically to important precedents resulting from yellow fever outbreaks in the southern United States in the nineteenth century."); see also Felice Batlan, Law in the Time of Cholera: Disease, State Power and Quarantines Past and Future, 80 TEMP. L. REV. 53, 64-65 (2007).

49. Kraut, supra note 4, at 29.

50. Price, supra note 34.

51. Id. at $936-37$.

52. 42 U.S.C. \& 264.

53. History of Quarantine, CTRS. FOR DisEASE CONTROL AND PREVENTION, https://perma.ce/M84FHXAJ (July 20, 2020).

54. Id. 


\section{Application of Federal Quarantine Power during COVID-19}

During fiscal year 2020, more than 197,000 people were expelled pursuant to the collection of orders, regulations, and memos referred to as the Title 42 Process along the southwest border. ${ }^{55}$ How did we get here?

The 1944 Regulations to Control Communicable Diseases set out and clarified the federal government's quarantine power. ${ }^{56}$ While prior to 1944 the federal government's quarantine power had often been in conflict with that of state and local governments, ${ }^{57}$ the 1944 Act made clear that the Surgeon General had authority to "make and enforce such regulations as in his judgment are necessary to prevent the introduction, transmission, or spread of communicable diseases from foreign countries into the States" as well as "from one State or possession into any other State or possession." "58

In addition, Section 265 of the Act granted authority to the Surgeon General to suspend entry of foreign nationals to the United States in the event of a "serious danger" of the introduction of a communicable disease:

Whenever the Surgeon General determines that by reason of the existence of any communicable disease in a foreign country there is serious danger of the introduction of such disease into the United States, and that this danger is so increased by the introduction of persons or property from such country that a suspension of the right to introduce such persons and property is required in the interest of the public health, the Surgeon General, in accordance with regulations approved by the President, shall have the power to prohibit, in whole or in part, the introduction of persons and property from such countries or places as he shall designate in order to avert such danger, and for such period of time as he may deem necessary for such purpose. ${ }^{59}$

It is this provision, section 268-which spells out the duties of consular officers and other officials to enforce these rules ${ }^{60}$ - a new regulation, several orders, and an implementation memo, ${ }^{61}$ that are being relied upon today to

55. FY 2020 Nationwide Enforcement Encounters: Title 8 Enforcement Actions and Title 42 Expulsions, U.S. CUSTOMS \& BORDER PROT., https://perma.cc/4QFU-DLD3 (Nov. 20, 2020).

56. Public Health Service Act, ch. 373, $\S 361,58$ Stat. 682, 703-04 (1944) (codified at 42 U.S.C. $\S 264)$.

57. Price, supra note 34, at $939-40$; Batlan, supra note 48 , at 67.

58. Public Health Service Act, 42 U.S.C. \$ 264(a).

59. 42 U.S.C. $\$ 265$.

60. 42 U.S.C. $\$ 268$ (") (a) Any consular or medical officer of the United States, designated for such purpose by the Secretary, shall make reports to the Surgeon General, on such forms and at such intervals as the Surgeon General may prescribe, of the health conditions at the port or place at which such officer is stationed. (b) It shall be the duty of the customs officers and of Coast Guard officers to aid in the enforcement of quarantine rules and regulations; but no additional compensation, except actual and necessary traveling expenses, shall be allowed any such officer by reason of such services.").

61. P.J.E.S. v. Wolf, 502 F. Supp. 3d 492, 505 (D.D.C. 2020) ("[T]he CAPIO Memo (COVID-I9 CAPIO instructed that when implementing the CDC Orders, agents may determine whether individuals are subject to the CDC Orders 'Based on training, experience, physical observation, technology, questioning and other considerations.' CAPIO Mem., ECF No. 15-5 at 15. If an individual was determined to be 
suspend the entry of certain noncitizens into the United States. Collectively, this Article, like the litigation that preceded it ${ }^{62}$ will refer to these provisions as the "Title 42 process." The remainder of this article will demonstrate why and how the Title 42 Process, which the government claims grants it the power to summarily remove a noncitizen absent a hearing, is in direct violation of the INA.

\section{Snapshots From Both Sides of the Border}

The following section intends to provide some narrative and texture to the Title 42 process by illuminating the experiences of advocates on both sides of the southwest border. Because it has been incredibly difficult to identify noncitizens directly impacted by Title 42 , as they are effectively disappeared into Mexico, dispersing upon arrival, this section focuses on qualitative interviews with advocates working directly with asylum seekers impacted by Title 42.

But before describing the realities faced by asylum seekers following the implementation of Title 42, we must understand what the world looked like pre-March 2020. Prior to the implementation of the Title 42 process, multiple executive orders, sub-regulatory guidance, and new regulations were conspiring to make the lives of asylum seekers in general, and Central American asylum seekers in particular, exceptionally difficult and dangerous.

Briefly, prior to March 2020, a Central American asylum seeker-and Brazilians as of January 2020 - traveling north to the US-Mexico border by foot could be expected to confront a number of obstacles. If she makes it to the Mexican border with the United States, she will first encounter "metering," a process by which Customs and Border Patrol ("CBP") now limits the number of noncitizens who can enter the United States on any given day. ${ }^{63}$ Her name will go on a list-a list that numbers in the thousands - and she will have to wait weeks, or months, for her number to be called. ${ }^{64}$ While she waits in Mexico, she is likely to be homeless, living in a shelter, and unable

\footnotetext{
subject to the CDC Orders, they were to be transported to the nearest POE and immediately returned to Mexico or Canada depending on their point of transit.' Id. at 17. The CAPIO Memo, 'provide[d] no instructions on medical screenings or other procedures for determining whether a covered noncitizen may have COVID-19,' Compl., ECF No. 1 at 17 II 68; and did 'not exempt minors from forcible expulsion,' id. at 18 पा 69.")

62. Compl. for Declaratory and Injunctive Relief at 1, Texas Civil Rights Project v. Wolf, No. 1:20cv-02035 (D.D.C. July 24, 2020); Compl. for Declaratory and Injunctive Relief at 1, G. Y. J. P. v. Wolf, No. 1:20-cv-01511-TNM (D.D.C. June 9, 2020); Compl. for Declaratory and Injunctive Relief at 1, J. B. B. C. v. Wolf, No. 1:20-cv-01509 (D.D.C. July 24, 2020).

63. For additional, in-depth discussion on metering, see Fatma E. Marouf, Executive Overreaching in Immigration Adjudication, 93 TUlANE L.R. 707, 763-68 (2019); see also Jennifer Lee Koh, Barricading the Immigration Courts, 69 DUKE L.J. ONLINE 48, 51, 56-58 (2020), https://perma.cc/3RKSUZKF.

64. Kirk Semple, What Is 'La Lista,' Which Controls Migrants' Fates in Tijuana?, N.Y. Times (Nov. 30, 2018), https://perma.cc/L4ZH-UL3M.
} 
to work. ${ }^{65}$ Increasingly, she will be vulnerable to organized crime, cartel violence, kidnappings, extortion from local government authorities, and, depending on her circumstances, continued harm from the persecutor(s) she fled, many of whom follow their victims north through Mexico. ${ }^{66}$ If she is traveling with children, when she is finally permitted to cross the border and present herself as an asylum seeker, she may be separated from them under the U.S. government's family separation or "zero tolerance" policy. ${ }^{67}$ Despite the Trump administration asserting that it has complied with court orders to suspend family separations, ${ }^{68}$ such separations in fact continued. ${ }^{69}$ And, as of January 29, 2019, because she is a Spanish speaking asylum seeker, she will be placed in the Migrant Protection Protocol ("MPP") program, ${ }^{70}$ and forced to wait for her U.S. immigration court hearing back in Mexico, along with more than 65,000 others. ${ }^{71}$ Suggestion to edit to: "as more than 70,000 others have done."

Indeed, as of February 2020, more than 57,000 non-Mexicans had been sent to Mexican border cities to await their asylum hearings as part of MPP. ${ }^{72}$ Of these 57,000, reports show that between 41,000 and 44,000 are Central American. ${ }^{73}$ And while they waited, in addition to hunger, homelessness, and illness, they faced significant danger. And yet, at least they were waiting for something - the promise of an opportunity to be heard in the United States,

65. Ashoka Mukpo, Asylum-Seekers Stranded in Mexico Face Homelessness, Kidnapping, and Sexual Violence, ACLU, https://perma.cc/Z9DG-XUQ9.

66. Id ; see also Julian Aguilar, Report: Crimes Against Migrants Waiting in Mexico to Seek U.S. Asylum Continue to Climb, TEX. TRIB. (Dec. 5, 2019), https://perma.cc/BF2Z-7565; HuMAN Rights FIRST, DELIVERED tO DANGER (current as of Feb. 19, 2021), https://perma.cc/8FRP-FTGA (documenting "at least 1,544 publicly reported cases of murder, rape, torture, kidnapping, and other violent assaults against asylum seekers and migrants forced to return to Mexico by the Trump Administration" as of February 19, 2021).

67. Sarah Sherman-Stokes, My Sharpie Marker Might Be the Only Thing Keeping Migrant Mothers and Children Together, USA TODAY (Apr. 24, 2019), https://perma.cc/VZE2-7Z4M [hereinafter Sherman-Stokes, My Sharpie Marker]; Sarah Sherman-Stokes, Neither Reckless Nor Improper: Central Americans' Search for Safety, HILL (June 7, 2018), https://perma.cc/YTE8-YR62

68. Richard Gonzales, ACLU: Administration Is Still Separating Migrant Families Despite Court Order to Stop, NPR (July 30, 2019, 7:15 PM), https://perma.cc/WY6E-WMH7.

69. See, e.g., Sherman-Stokes, supra note 67; see also Leila Rafei, Family Separation, Two Years After Ms. L, ACLU (Feb. 26, 2020), https://perma.cc/6MXV-EQLS.

70. See Immigration and Nationality Act, 8 U.S.C. $\$ 1225(\mathrm{~b})(2)(\mathrm{C})$; Memorandum from Kristjen Nielsen, Sec'y of Dep't of Homeland Sec. to L. Francis Cissna, Dir., U.S.C.I.S., Kevin K. McAleenan, Comm'r, U.S. Customs and Border Prot. \& Ronald D. Vitiello, Deputy Dir., I.C.E. on Policy Guidance for Implementation of the Migrant Protection Protocols (Jan. 25, 2019).

71. See Details on MPP (Remain in Mexico) Deportation Proceedings, TRAC IMMUGRATION, https:// perma.cc/FAA3-EWU7 (showing as of October 2020, at least 68,430 migrants had been subject to MPP); see also Maria Sacchetti, Kevin Sieff \& Nick Miroff, Federal Appeals Court Blocks President Trump's 'Remain in Mexico' Policy but Stays its Own Ruling, WASH. POST (Feb. 28, 2020), https://perma.cc/ E3YB-4CS7.

72. Central Americans Sent to Mexico by U.S. Increasingly Victims of Kidnappings: Aid Group, REUTERS (Feb. 11, 2020, 12:07 PM), https://perma.cc/Z7U7-52A7.

73. Assessment of the Migrant Protection Protocols (MPP), DeP'T OF Homeland Sec. (Oct. 28, 2019), https://perma.cc/ZWE4-J92Z (stating that DHS has returned 55,000 noncitizens to Mexico); $Q \&$ A: Trump Administration's "Remain in Mexico" Program, Hum. RTs. WATch (Jan. 29, 2020, 10:00 AM), https://perma.cc/S393-7Z34 (revealing that 21,786 in the MPP are from Honduras; 15,009 from Guatemala; 7,668 from El Salvador; 1,414 from Nicaragua). 
and to make out their claims for asylum. Just one month later, that would all change with the implementation of an unforgiving asylum ban that left tens of thousands of would-be asylum seekers without a way forward. The following section describes two organizations on the ground, who were on the front lines as Title 42 implementation unfolded.

\section{Al Otro Lado}

Al Otro Lado is a bi-national, direct legal services organization with offices in Los Angeles, San Diego and Tijuana, Mexico, serving indigent deportees, migrants, and refugees. ${ }^{74} \mathrm{Al}$ Otro Lado is also consistently active in bringing litigation to challenge the ongoing human rights violations of the U.S. government as regards immigrants, refugees, and asylum seekers. Particularly relevant to this article, Al Otro Lado's Tijuana office provides legal orientation and know-your-rights trainings to asylum seekers in Tijuana who wish to present themselves to U.S. authorities to seek asylum. ${ }^{75}$ In this way, Al Otro Lado is well-positioned to provide a window into the realities faced by those asylum seekers who, but for the Title 42 Process, would be pursuing asylum within the United States. In addition, Al Otro Lado can share the stories of those who attempted to cross the border to seek asylum but were immediately removed pursuant to the Title 42 Process.

\section{Florence Immigrant and Refugee Rights Project ("Florence Project")}

The Florence Project is a nonprofit legal service organization providing free legal and social services to adults and unaccompanied children in immigration custody in Arizona. ${ }^{76}$ Prior to implementation of the Title 42 Process, there were approximately 3-4,000 people in immigration custody on any given day in Arizona. ${ }^{77}$ The Florence Project's Border Action Team, working together with the Kino Border Initiative in Nogales, Arizona and Mexico, is also well equipped to document the realities faced by asylum seekers on both sides of the U.S.-Mexico border.

The populations served by Al Otro Lado and the Florence Project represent significant communities of Central American asylum seekers in both Mexico and the United States, in two different border regions, Tijuana/San Ysidro and Nogales. The experiences of the communities served by these organizations provide a window into the devastation wreaked by racist immigration policies masquerading as public health responses.

\section{A. "Central American Asylum Seekers Are Rendered Invisible By Title 42."}

A recurring theme from advocates at both $\mathrm{Al}$ Otro Lado and the Florence Project was that asylum seekers are effectively rendered invisible by the Title

74. About Us, AL OTRO LADO, https://perma.cc/KPV8-3ZSS.

75. Border Rights Project, AL OTRO LADO, https://perma.cc/4TH9-6Z7H.

76. About Us, FlorenCE IMMigRant \& REFUGEe RTS. PROJECT, https://perma.cc/288Z-AF5L.

77. See FY 2019 Detention Statistics, IMMIGR. AND CusToMs ENF'T, https://perma.cc/8D6H-67ZH; FY 2020 Detention Statistics, IMMIGR. AND CuSTOMS ENF'T, https://perma.cc/8D6H-67ZH. 
42 Process. Attorneys from both organizations noted that it was "really hard to get demographics because of the way Title 42 is enforced" and that the "problem" of this order is "made invisible."78 U.S. Customs and Border Protection has released limited data on the number of Title 42 expulsions. The numbers reveal more than 197,000 during FY $2020{ }^{79}$ In a lawsuit filed in the D.C. District Court, plaintiffs alleged that more than 13,000 of these expulsions were of unaccompanied children. ${ }^{80}$ And yet, longtime organizations working on both sides of the border have been able to identify very few of those impacted.

The Title 42 process means that, since March 2020, when non-Mexican asylum seekers have presented themselves at ports of entry, they have been expelled immediately under the Title 42 process. ${ }^{81}$ And, indeed, this is the case for Mexican migrants, who are usually quickly and immediately returned to Mexico. ${ }^{82}$ But for non-Mexican asylum seekers-the majority of whom are Central American ${ }^{83}$ - it takes time to coordinate their removals, as travel documents and flight accommodations must be made. As a result, these asylum seekers are often subject to exactly what the U.S. government has said it cannot do for public health reasons: ${ }^{84}$ hold noncitizens in congregate settings. In FY 2020, at least 900 people have been held by ICE in hotels, which are not subject to the same health and safety guidelines as federal detention centers. ${ }^{85}$ Noncitizens are often held in these hotels for days or weeks before they can be expelled to their home countries. ${ }^{86}$ An attorney on the Florence Project's Border Action Team reported working to provide legal support to an unaccompanied child held in a hotel, as ICE actively moved to deport him. ${ }^{87}$ Ultimately, the Florence Project was successful in getting him placed with the Office of Refugee Resettlement ("ORR") but the attorney

78. Zoom interview with Soraya Vazquez, Deputy Dir., Al Otro Lado, Tijuana Office (Aug. 13, 2020) (on file with author).

79. FY 2020 Nationwide Enforcement Encounters: Title 8 Enforcement Actions and Title 42 Expulsions, U.S. CuSTOMS AND BORDER PROT. (Nov. 20, 2020), https://perma.cc/XN32-PUDP.

80. Pl.'s Notice Regarding Pending Mot. for Prelim. Inj., P.J.E.S. v. Wolf, 502 F. Supp. 3d 492 (D.D. C. 2020) (No. 1:20-cv-02245-EGS) (alleging that the number of expelled unaccompanied children had "exceeded 13,000 by the end of October").

81. Suspension of entries and imports from designated places to prevent spread of communicable diseases, 42 U.S.C. $\$ 265$.

82. Interview with Soraya Vazquez, supra note 78 ("C $[\mathrm{W}]$ hat I've seen is that the people who are being expelled [who we find], are Mexican.").

83. Caitlin Dickerson, 10 Years Old, Tearful and Confused After a Sudden Deportation, N.Y. TIMES (Oct. 21, 2020), https://perma.cc/X3NG-TE2Z ("Since the coronavirus was first discovered in the United States in January, 239 unaccompanied minors have been returned to Guatemala, and 183 have been returned to Honduras, according to government figures.").

84. COVID-19 CAPIO, U.S. CUSTOMS AND BORDER PROT., https://perma.cc/U8UJ-TAF7; see also Guttentag, supra note 13 (noting that the CBP directive's "stated rationale is the risk alleged from 'covered aliens' being crowded in 'congregate settings.' The apparent justification for bypassing all legal protections and procedures is the CBP's assertion that Border Patrol officers are 'not operating pursuant to' their authority under the immigration laws.").

85. Dickerson, supra note 83 .

86. See id.

87. Zoom interview with Alexandra Miller, Esq. Border Action Team Managing Attorney at FIRRP (Aug. 13, 2020) (on file with author). 
reported that such success was anomalous. ${ }^{88}$ A child was much more likely to meet the fate of Gerson, profiled by the New York Times in August 2020. Gerson, at just 10 years old, was one of 915 migrant children expelled to his home country under Title $42 .{ }^{89}$ Rather than being offered the kinds of protections that migrant children are required to be provided under the law, ${ }^{90}$ Gerson was effectively disappeared by the U.S. government for six days before landing in Honduras, disoriented and confused about how he arrived back in the country he had only recently fled in fear. ${ }^{91}$

\section{B. "There Is No Asylum Anymore."}

Asylum is a form of protection and legal status granted to noncitizens already in the United States or arriving at the border or a port of entry who meet the definition of a "refugee." 92 A refugee is defined as "a person who is unable or unwilling to return to his or her home country, and cannot obtain protection in that country, due to past persecution or a well-founded fear of being persecuted in the future on account of race, religion, nationality, membership in a particular social group, or political opinion." ${ }^{.93}$

Although the United States had several ad hoc programs for admitting refugees following World War II, it wasn't until 1965 that Congress created a preference category explicitly for refugees, though limited to those fleeing the Middle East or communist-controlled territories. ${ }^{94}$ Fifteen years later, with the Refugee Act of 1980, asylum was explicitly made available to individuals fleeing violence in noncommunist countries. ${ }^{95}$ Still, the 1980s and early 1990s saw challenges to what remained a lopsided system, favoring asylum for those fleeing communist governments. ${ }^{96}$ A series of lawsuits led

\footnotetext{
88. Id.

89. Dickerson, supra note 83.

90. Claudia G. Catalano, Annotation, Validity, Construction, and Application of Section 112 of Trafficking Victims Protection Act of 2000 and Subsequent Reauthorizing Provisions amending Chapter 77 of Title 18, United States Code, 75 A.L.R. Fed. 2d 467 (2013).

91. Dickerson, supra note 83.

92. Asylum in the United States, Am. IMMigr. Council (June 11, 2020), https://perma.cc/J9PE$8 \mathrm{FCM}$.

93. Id.; see 1951 Convention Relating to the Status of Refugees, July 28, 1951, 189 U.N.T.S. 137 ; 1967 Protocol relating to the Status of Refugees, Oct. 4, 1967, 606 U.N.T.S. 267.

94. See Hart-Celler Act, Pub. L. No. 89-236, 79 Stat. 911 (1965); The Refugee Act of 1979, S. 643. Hearing Before the S. Comm. on the Judiciary, 96th Cong. 9 (1979) (statement of former Senator, newly appointed U.S. Coordinator for Refugee Affairs, Dick Clark) (testifying that prior to 1980, refugee programs were a "patchwork" of different programs "originally designed to deal with people fleeing communist regimes in Eastern Europe or repressive governments in the Middle East").

95. See Refugee Act of 1980, Pub. L. No. 96-212, 94 Stat. 102.

96. STEPHen H. Legomsky \& CRistina M. Rodríguez, Immigration and ReFugee LAw and POLICY 1032-33 (5th ed. 2009) (describing historical accusations of political bias in the asylum system). Asylum grant rates for Salvadorans and Guatemalans in 1984 were both under 3\%. In stark contrast, "the approval rate for Iranians was 60 percent, 40 percent for Afghans fleeing the Soviet invasion, and 32 percent for Poles." Susan Gzesh, Central Americans and Asylum Policy in the Reagan Era, MigRATION POL'y INST. (Apr. 1, 2006), https://perma.cc/6AG2-DPHV.
} 
to some reforms in the $1990 \mathrm{~s}$, including new asylum regulations, the creation of an asylum officer corps, ${ }^{97}$ and Temporary Protected Status ("TPS"). ${ }^{98}$

The last two years have seen a dramatic shift in asylum-from a narrowing of what constitutes a cognizable claim for asylum ${ }^{99}$ to new and cruel federal immigration policies that ban asylum seekers at the border ${ }^{100}$ and require would-be asylum seekers to wait for months in Mexico, rather than in the United States. ${ }^{101}$ The Trump administration, arguably more than almost any other, has taken pains to dramatically limit the scope of asylum, targeting Central American asylum seekers with particular animus and precision. And while the Biden administration made promises on the campaign trail to walk back these changes, after more than nine months in office, painfully little progress has been made. ${ }^{102}$

And yet, despite policy, law, and rhetoric aimed at deterring would be asylum seekers from coming to the United States, asylum remains an available legal option for immigration relief: it is written into the statute and codified in the regulations. ${ }^{103}$ It may come as something of a surprise, then, that attorneys at both Al Otro Lado and the Florence Project report their clients being told by CBP officers, "asylum does not exist anymore." ${ }^{104}$ Such assertions, while perhaps in line with previous claims that CBP often acts as a rogue agency ${ }_{105}$ are a dangerous departure from law and precedent. They send the message that a pathway to protection by which we are legally bound-and have been for more than fifty years-is no longer available.

In the early days of the Migrant Protection Protocols/Remain in Mexico policies, which directed would-be asylum seekers to ports of entry to seek protection, advocates often accompanied particularly vulnerable asylum seekers, including children, LGBTQI, and the mentally and physically ill

97. Robert Pear, U.S. Issues Asylum Rules Praised as Fairer to Aliens, N.Y. TIMES, July 19, 1990, at A16.

98. Immigration Act of 1990, Pub. L. No. 101-649, § 302(a), 104 Stat. 4978, 5030-36.

99. See e.g., Matter of A-B-, 27 I. \& N. Dec. 316 (A.G. 2018); Matter of L-E-A-, 28 I. \& N. Dec. 304 (A.G. 2021); Matter of A-C-A-A-, 28 I. \& N. Dec. 84 (A.G. 2020).

100. Interim Final Rule: Asylum Eligibility and Procedural Modifications, 84 Fed. Reg. 33,829 (July 16, 2019) (to be codified at 8 C.F.R. pt. 208, 1003, 1208); Aliens Subject to a Bar on Entry Under Certain Presidential Proclamations; Procedures for Protection Claims, 83 Fed. Reg. 55,934, 55,934-35 (Nov. 9 , 2018) (to be codified at 8 C.F.R. pt. 208, 1003, 1208).

101. Memorandum from U.S.C.I.S. on Guidance for Implementing Section $235(\mathrm{~b})(2)(\mathrm{C})$ of the Immigration and Nationality Act and the Migrant Protection Protocols (Jan. 28, 2019).

102. See, e.g., Julio Ricardo Varela, Opinion, Deportations, Children in Detention and Calls to 'Not Come' Show Biden is Failing on Immigration, WASH. POST, Aug. 3, 2021, https://perma.cc/UN5CVBKY.

103. 8 U.S.C. $\S 1158(a)(1) ; 8$ C.F.R. § 208.13

104. Interview with Alexandra Miller, supra note 87

105. Jennifer Lee Koh, Removal in the Shadows of Immigration Court, 90 S. CAL. L. REv. 181, 23031 (2017); see also Lindsay M. Harris, Withholding Protection, 50 Colum. Hum. RTS. L. REV. 1, 32-37 (2019); Michele R. Pistone \& John J. Hoeffner, Rules Are Made to Be Broken: How the Process of Expedited Removal Fails Asylum Seekers, 20 GEO. IMMIGR. L.J. 167, 196 (2006); Nina Rabin, Victims or Criminals? Discretion, Sorting, and Bureaucratic Culture in the U.S. Immigration System, 23 S. CAL. REV. L \& SOC. JUST. 195, 199 (2014). 
across the border. ${ }^{106}$ Since the implementation of the Title 42 Process, when advocates have tried to accompany their most vulnerable clients across the border or file "humanitarian parole"107 requests for their entry on humanitarian grounds, CBP has responded with closed doors. ${ }^{108}$ One attorney from the Florence Project who has accompanied, among others, a woman with a high risk pregnancy suffering from preeclampsia and hypertension, was told "we don't have capacity" and "our hands are tied." 109 In fact, in all cases in which the Florence Project has accompanied extremely vulnerable asylum seekers since the beginning of the Title 42 Process, CBP has refused to let the asylum seeker cross. ${ }^{110}$

Finally, these refusals and assertions that asylum "does not exist anymore" have a disproportionate impact on Central American asylum seekers who continue to make up the bulk of those crossing, or attempting to cross, the southwest border. Last year 73 percent of those apprehended by CBP at the southwest border were Central American. ${ }^{111}$

\section{C. "There Has Always Been Worry, But Now There Is Despair."}

Prior to March 2020, and especially under the Trump administration, to seek asylum in the United States was to submit oneself to a series of seemingly insurmountable obstacles. Merely getting to the United States, to a port of entry, and in front of an officer to request asylum became more difficult than nearly ever before. ${ }^{112}$ But after the implementation of Title 42 , a process that was always difficult became almost impossible.

Describing the months leading up to March 2020, advocates don't mince words: "it was horrible." 113 Advocates describe deep worry, an ever-changing landscape, and a constant desire for answers on the part of refugees. ${ }^{114}$ Migrants and asylum seekers wondered whether they would have an attorney, whether laws would change, and what their individual process would look

106. Hum. RTS. WATCH, "We CAN'T Help You HeRE:" US Returns of Asylum SeEkeRs to MEXICO 42 (2019), https://perma.cc/4GRZ-DQ9W.

107. See, e.g., Julián Aguilar, This Asylum Seeker Fled to Texas to Escape Violence, Only to Test Positive for Coronavirus While Fighting Deportation, TEX. TRIB. (July 14, 2020, 5:00 PM), https:// perma.cc/4WSE-J7XN.

108. Interview with Alexandra Miller, supra note 87.

109. Id.

110. Id. Ms. Miller noted that "[t]here are exceptions built into MPP, Title 42 and DHS guidelines and there's no guidance as to what these exceptions mean." See also Migrant Protection Protocols, U.S. DEP'T OF HOMELAND SEC. (Jan. 24, 2019), https://perma.cc/QQ3P-WKJZ ("With certain exceptions, MPP applies to aliens arriving in the U.S. on land from Mexico (including those apprehended along the border) who are not clearly admissible and who are placed in removal proceedings under INA $\$ 240$. .").

111. Southwest Land Border Encounters, U.S. CuSTOMS AND BORdeR PROT., https://perma.cc/ E3JX-3M4F (last modified Sept. 3, 2021).

112. See Lindsay M. Harris, Asylum Under Attack: Restoring Asylum Protection in the United States, 67 LOY. L. REV. 121, 127 (2020).

113. Interview with Soraya Vazquez, supra note 78.

114. Id.; Interview with Alexandra Miller, supra note 87. 
like. ${ }^{115}$ But, they acknowledge, "cases were advancing" and people "saw a future," despite the formidable barriers of metering, family separation, and MPP. ${ }^{116}$ In some sectors, family units were being allowed to enter without prolonged detentions, and parole was possible, especially for extremely vulnerable populations like the LGBTQ community, the physically and mentally ill, and children. ${ }^{17}$

Following the swift implementation of Title 42 in March 2020, advocates describe a palpable shift. What was once worry among migrants, became "an anguish to survive." ${ }^{118}$ Suddenly, closed borders and a global pandemic meant that volunteer bodies and dollars were no longer coming into Mexico. ${ }^{119}$ Shelters that asylum seekers and migrants relied on closed and donations dried up. ${ }^{120}$ The majority of migrants and asylum seekers waiting in Mexico have no lawful status there, and no work permit, making their ability to survive and support themselves increasingly challenging. ${ }^{121}$ Advocates describe a "state of collective frustration" and an increase in anxiety, depression and hopelessness. ${ }^{122}$ With little information and cases effectively at a complete standstill, asylum seekers and refugees are feeling a compounding sense of despair. ${ }^{123}$

\section{D. "If They Stay, They Can Be Killed.If They Flee, They Can Be Killed."}

As detailed in Part I, Central Americans are fleeing significant violence, persecution and torture in the Northern Triangle. Most often, they come to the United States seeking safety and protection from transnational criminal organizations and family/domestic violence. ${ }^{124}$ Despite the dramatic changes to asylum law in the last several years, and since March 2020 in particular, the factors pushing Central Americans to leave their homes have remained fairly steady. What has changed are the numerous challenges they encounter in their journeys to seek protection. ${ }^{125}$ As one advocate lamented, "the harms

115. Interview with Soraya Vazquez, supra note 78.

116. Id.

117. Interview with Alexandra Miller, supra note 87.

118. Id.

119. Id.

120. Id.

121. Id.

122. Id.

123. Interview with Alexandra Miller, supra note 87 ("There has always been worry, but now there is despair.").

124. U.N. High Comm'n For Refugees, ChIldren on the Run: Unaccompanied Children Leaving Central America and Mexico and the NeEd for International Protection 6 (2014), https://perma.cc/3JME-HUAE [hereinafter CHILDREN ON THE RuN]; U.N. HIGH COMM'R FOR REFUGEES, Women on the Run, First-Hand accounts of Refugees Fleeing El Salvador, Guatemala, HONDURAS, AND MEXICO 15-16 (2015), https://perma.cc/S5R6-7DQ5 [hereinafter WOMEN ON THE RUN].

125. See The Devastating Toll of "Remain in Mexico" One Year Later: US Government's Migrant Protection Protocols Put Tens of Thousands at Risk, DoCTORS WiTHOUT Borders (Jan. 29, 2020), https://perma.cc/E3DZ-BD7N (80\% of migrants treated by Doctors Without Borders in Nuevo Laredo, Mexico reported having been the victim of one or more violent incidents. Almost $50 \%$ of migrant patients reported having been the victims of violence within seven days prior to being treated); see also Tom Phillips, Trump's 'Shameful' Migrant Stance Condemns Thousands to Violent Limbo in Mexico, 
they are fleeing are real," but now, oftentimes "the risks they are fleeing reach them here [along the border]."126

The confluence of metering, family separation, MPP, and now Title 42 has meant that tens of thousands of exceptionally vulnerable, under-resourced asylum seekers have become proverbial sitting ducks in Mexican border towns. These changes have not gone unnoticed. Asylum seekers increasingly face persecution in Mexico while they wait for their claims to be heard. Advocates recount story after story of kidnappings, cartel violence, gang violence, extortion by both Mexican police and immigration officials, and human trafficking. ${ }^{127}$

These accounts are corroborated by official reports. In February 2020, just before Title 42 took hold, Doctors Without Borders reported that 75 percent of their patients in one border town had been kidnapped while in Mexico, waiting for their hearings. ${ }^{128}$ Advocates report that kidnapping has become "a whole new sector" of the cartel business in Mexico. ${ }^{129}$ A staggering $80 \%$ were survivors of some kind of violence while waiting in Mexico. ${ }^{130}$ Indeed, migrants are targeted "because they're migrants."'131 While this Article focuses on the history of discrimination and racism directed at Central American migrants in particular, it is important to note that Black migrants waiting in Mexico face significant violence because of the color of their skin. For example, in the spring of 2021, it was estimated that in Tijuana alone there were between three and five thousand Black migrants waiting to cross the border, and nongovernmental organizations documented patterns of police violence, detention, racism and discrimination experienced disproportionately by this community. ${ }^{132}$

\section{The Legacy of Racism Directed Toward Central American REFUGEES}

This latest assault on asylum that disproportionately impacts Central Americans is not an aberration. Title 42 effectively closing the door on asylum for anyone from Central America-and indeed on disproportionately low income Black and Brown immigrants-comes on the heels of years of immigration law and policy pushing asylum increasingly out of reach.

Guardian (Dec. 20, 2019, 4:30 AM), https://perma.cc/54BJ-Q2SP; Kirke Semple, Migrants in Mexico Face Kidnappings and Violence While Awaiting Immigration Hearings in U.S., N.Y. TIMES (July 12, 2019), https://perma.cc/BQ4W-5NKS.

126. Interview with Soraya Vazquez, supra note 78.

127. Id:; Interview with Alexandra Miller, supra note 87.

128. No Way Out: MSF Report Shows Damaging Health Impacts of US-Mexico Migration Policies, DOCTORS WITHOUT BORDERS (Feb. 11, 2020), https://perma.cc/VM9G-PP7N.

129. Interview with Alexandra Miller, supra note 87.

130. No Way Out, supra note 128.

131. Interview with Alexandra Miller, supra note 87.

132. Nisha Venkat, Black Immigrants Are Facing Rampant Racism in Mexico While Waiting for US Asylum: "We Have No Choice," BuzzFEEd NEws (Mar. 27, 2021, 11:13 AM), https://perma.cc/FD63ZV2W. 
Since the creation of modern U.S. asylum law with the Refugee Act of 1980, Central American migrants and asylum seekers have faced systemic discrimination and racism in the U.S. immigration system. ${ }^{133}$ This section will focus specifically on the injustices faced by Central American asylum seekers as they struggle to seek protection in the United States, and will set the stage for illuminating the disproportionate impact of today's COVID-19 quarantine order on Central American refugees.

Modern day asylum law and precedent were, and continue to be, heavily influenced by the migration patterns of Central American asylum seekers, and U.S. government efforts to exclude Central Americans from protection. ${ }^{134}$ Soon after the passage of the 1980 Refugee Act, migration patterns to the United States shifted dramatically. This shift was largely because of civil war and U.S. intervention and human rights abuses across Central America. In 1980, there were 354,000 Central Americans living in the United States; by 1990 , that number had more than tripled to $1,134,000{ }^{135}$ By 2017 , the number had grown to $3,527,000$, with immigrants from El Salvador, Guatemala, and Honduras-the Northern Triangle countries-accounting for 1350 percent growth by each group since $19800^{136}$

As more Central American asylum seekers sought protection, the Board of Immigration Appeals issued a series of precedential decisions ${ }^{137}$ illuminating the harms Central American migrants were fleeing - the factors driving them to leave their homes in fear for their lives. The severe violence of civil wars in which the United States and its military played a significant role in perpetrating grave human rights abuses, which led to hundreds of thousands of deaths across the region. ${ }^{138}$ It was largely this violence that ultimately drove Central American migration north in unprecedented numbers. ${ }^{139}$

133. See, e.g., Sherman-Stokes, supra note 2; see also Ann Aita, Note, What About Us? NACARA's Legacy and the Need to Provide Equal Protection to Guatemalan, Nicaraguan, Salvadoran, and Honduran Residency-Seekers in the United States, 32 RuTGERS L.J. 341, 344 46 (2000); Susan Bibler Coutin, Falling Outside: Excavating the History of Central American Asylum Seekers, 36 L. \& Soc. INQUIRY 569, 570, 581 (2011); Daniel L. Swanwick, Foreign Policy and Humanitarianism in U.S. Asylum Adjudication: Revisiting the Debate in the Wake of the War on Terror, 21 GEO. IMMIGR. L.J. 129, 130 (2006); Michael J. Churgin, Mass Exoduses: The Response of the United States, 30 INT'L MigRATION REV. 310, 319-20(1996).

134. See Matter of A-B-, 27 I. \& N. Dec. 316 (A.G. 2018); see also Matter of S-E-G-, 24 I. \& N. Dec. 579 (B.I.A. 2008); Matter of Acosta, 19 I. \& N. Dec. 211 (B.I.A. 1985).

135. Allison O'Connor, Jeanne Batalova \& Jessica Bolter, Central American Immigrants in the United States, Migration POL'y InST. (Apr. 5, 2017), https://perma.cc/LV39-TX9Z (noting that the population of Central Americans living in the United States tripled between 1980 and 1990, and was 3.5 million by 2017 ).

136. $I d$.

137. See, e.g., Matter of Acosta, 19 I. \& N. Dec. 211 (B.I.A. 1985).

138. For a selection of works detailing significant and ongoing U.S. involvement in massacres, wars, and related human rights abuses across Central America, see MARK DANNER, ThE MASSACRE At EL Mozote (1st ed. 1994); Stephen Kinzer, Blood Of Brothers: Life And War In Nicaragua (1991); STEPHEN SCHLesinger \& STePHEn KinZer, BitTer FrutT: The Story OF The American Coup In Guatemala (2d ed. 1982); see also Karen Musalo, El Salvador-A Peace Worse Than War: Violence, Gender and a Failed Legal Response, 30 YALE J.L. \& FEMINISM 3, 11 (2018).

139. It is commonly estimated that 55,000 to 75,000 Salvadorans, approximately one in every 66 Salvadorans, died in war-related violence. See Mitchell A. Seligson \& Vincent McElhinny, Low-intensity 
As tens of thousands of Central Americans were killed across the region during the 1980s and 1990s, many survivors fled north. ${ }^{140}$ Upon arrival in the United States, they were met with systemic discrimination driven largely by an anti-communist agenda. ${ }^{141}$ Those fleeing communist countries were much more likely to be granted asylum as compared to those fleeing dictatorships supported by the United States government. ${ }^{142}$ This unequal response came to a head in 1985 when more than eighty religious and refugee groups brought suit in federal court, challenging the patterns of discrimination in asylum cases involving Salvadorans and Guatemalans. ${ }^{143}$ They sued the Immigration and Naturalization Service ("INS"), the Executive Office for Immigration Review ("EOIR") - an office of the Department of Justice ("DOJ") responsible for adjudicating all immigration cases-and the Department of State ("DOS"). ${ }^{144}$ That lawsuit, now commonly referred to as the "ABC Case," alleged that the government's discriminatory practices violated the rights of noncitizens and asylum seekers. ${ }^{145}$ Though the parties reached a settlement in 1990, and certain guardrails and protective measures were instituted-ostensibly to protect the rights of Central American asylum seekers - discrimination and animus persisted within the U.S. immigration system. ${ }^{146}$

Two decades later, immigration patterns had shifted again. In contrast to the preceding years, in which the primary population migration from the Northern Triangle were men traveling alone, starting in 2011, the United States saw a dramatic increase in the number of people, and specifically unaccompanied immigrant children, migrating from the Northern Triangle. ${ }^{147}$ Many were seeking protection from gang violence and domestic/intra-family violence. ${ }^{148}$ This migration peaked in fiscal year 2014, when the U.S. Border Patrol apprehended nearly 52,000 Central American children crossing the U.S.-Mexico Border. ${ }^{149}$ Subsequent interviews with migrants conducted by the United Nations High Commissioner for Refugees ("UNHCR") found that

\footnotetext{
Warfare, High-intensity Death: The Demographic Impact of the Wars in El Salvador and Nicaragua, 21 Canadian J. LATIN AM. \& Caribbean STUd. 211, 214-15, 226-29 (1996); see also Guatemala, CTR. FOR JUST. \& ACCOUNTABILITY, https://perma.cc/H7U4-5M29 ("Over 200,000 Guatemalans were killed or forcibly disappeared in a civil war that raged from 1960-1996.").

140. See Bill Ong Hing, Mistreating Central American Refugees: Repeating History In Response to Humanitarian Challenges, 17 HASTIngS RACE \& POVERTY L.J. 359, 361 (2020); see also Susan Bibler Coutin, Falling Outside: Excavating the History of Central American Asylum Seekers, 36 L. \& SoC. INQUIRY 569, 569-70 (2011).

141. Id. at $361-62$.

142. $I d$.

143. Am. Baptist Churches v. Thornburgh, 760 F. Supp. 796, 799 (N.D. Cal 1991).

144. Id.

145. Id. at 830 .

146. See Hing, supra note 140 , at 367-68.

147. See DHS Off. Of Immigr. Stat., Immigration Enforcement Actions: 2019, at 4 (2019), https://perma.cc/PKX8-PEB7 [hereinafter Immigration Enforcement Actions 2019 Report].

148. See CHILdREN ON THE Run supra note 124 , at 6-7.

149. DHS OfF. OF IMMigr. STAT., IMMigration ENFORCEMENT ACTIONS: 2014, at 4 (2014), https:// perma.cc/QB3E-9TYK; see also Immigration Enforcement Actions 2019 Report, supra note 147, at 5 fig.2.
} 
nearly two-thirds of these children met the definition of a "refugee," and therefore qualified for protection under U.S. domestic and international law. ${ }^{150}$ The children and women who fled the Northern Triangle during that period were forced to flee by horrific violence. Those interviewed by the UNHCR reported witnessing - and surviving — shocking levels of violence in their home countries. For example, eighty-five percent of women interviewees reported living in a neighborhood controlled by gangs or other violent criminal groups. ${ }^{151}$ They also reported "prolonged instances of physical, sexual, and psychological domestic violence, for which authorities provided no meaningful help." ${ }^{152}$ It was this enduring violence coupled with impunity for the perpetrators that forced thousands of Central Americans to seek refuge in the United States. ${ }^{153}$

Republican presidents do not stand alone in their seeming inability to treat to immigrants and asylum seekers with dignity and respect. Under the Obama administration, upon arriving in the United States, Central Americans were not welcomed with compassion, humanity, or the protections that asylum law promised survivors of torture and persecution. The Obama administration was responsible for large scale family detention, a significant increase in deportations, and declining grants of asylum. ${ }^{154}$ Indeed, under the Obama administration, Central Americans were singled out. During 2014 alone, CBP apprehended more than 200,000 Guatemalans and Hondurans, the vast majority of them seeking protection. ${ }^{155}$ At that time, during a visit to the Guatemalan Embassy, then-Vice President Biden spoke directly to these migrants and asylum seekers, saying "we're going to send the vast majority of you back." 156 Today, President Biden has continued to push this agenda, carrying out fast track deportation flights to Central America despite significant health risks ${ }^{157}$ and bluntly telling Central American asylum seekers "[d] o not come." 158

150. See CHILdREN ON THE Run supra note 124, at 6; see also Laila L. Hlass, Minor Protections: Best Practices for Representing Child Migrants, 47 N.M.L. REv. 247, 256 (2017).

151. WOMEN ON THE RUN, supra note 124 , at 4.

152. Id. at 25 .

153. See Id. at 15-30; CHLLden ON THE RUN supra note 124, at 24-29.

154. Lindsay M. Harris, Contemporary Family Detention and Legal Advocacy, 21 HARv. LATINX L. REv. 135 (2018); Dora Schriro, Weeping in the Playtime of Others: The Obama Administration's Failed Reform of ICE Family Detention Practices, 5 J. ON MIGRATION \& HuM. SEC. 452 (2017); Marcia Zug, The Mirage of Immigration Reform: The Devastating Consequences of Obama's Immigration Policy, $63 \mathrm{U}$. KAN. L. REV. 953 (2015).

155. 2014 Yearbook of Immigration Statistics, Table 34 Aliens Apprehended by Region and Country of Nationality: Fiscal Years 2012 to 2014, U. S. DEPT. OF HOMELAND SECURITY, https://perma.cc/T9CG4X3T (last updated Nov. 16, 2018).

156. Remarks to the Press with Q\&A by Vice President Joe Biden in Guatemala (June 20, 2014), https://perma.cc/FVA8-8HC4.

157. Nick Miroff \& Maria Sacchetti, Biden Resumes Fast-Track Deportation Flights for Migrant Families, but Many Unable to Travel After Positive Covid Tests, WASH. POST (July 30, 2021, 5:28 PM), https://perma.cc/C68G-VLGG.

158. Cleve R. Wootson Jr., Harris Wraps up a Latin America Trip That Featured Sharp Words to Would-Be Immigrants, WASH. POST (June 8, 2021, 9:58 PM), https://perma.cc/QL63-J5JC. 
Central Americans have faced increased apprehension, detention, criminalization, family separation, unceasing efforts at "deterrence," and a dramatic narrowing of protections provided by asylum law. A full and total accounting of the executive orders, policies, cases and sub-regulatory guidance that together have made asylum nearly unattainable for Central American refugees, while important, is outside the scope of this paper. ${ }^{159}$ Briefly, however, Lindsay M. Harris categorizes these broad changes into six groups: ${ }^{160}$ (1) border policies constricting access to asylum; ${ }^{161}$ (2) asylum "bans"; ${ }^{162}$ (3) Attorney General decisions changing the shape of asylum law; ${ }^{163}$ (4) bureaucratic shifts; ${ }^{164}$ (5) co-opting of the COVID-19 public health crisis; ${ }^{165}$ and (6) sweeping and comprehensive "Death to Asylum" proposed regulations issued in June $2020 .{ }^{166}$ While this paper will focus primarily on the co-opting of the COVID-19 public health crisis, I mention these additional attacks on U.S. asylum law to highlight the profound and sweeping changes that have transpired in the last several years alone. Indeed, the COVID-19 public health crisis has only brought into clearer view the devastating impact of these changes on the fate of asylum seekers.

\section{Title 42 Alternatives}

At the time of publication, the United States is embarking on a new presidential administration, under President Biden. Some changes have been swift. During his first twenty-four hours in office, President Biden signed

159. For that paper, see Lindsay M. Harris, Asylum Under Attack, 67 LoY. L. REv. (forthcoming 2021).

160. See id.

161. See Implementing Bilateral and Multilateral Asylum Cooperative Agreements Under the Immigration and Nationality Act, 84 Fed. Reg. 63,994 (proposed Nov. 19, 2019) (to be codified at 8 C.F. R. pt. 208, 1003, 1208, and 1240); INA $\$ 235$ (b)(2)(C), 8 U.S.C. $\$ 1225$ (b)(2)(C); Safe Third Country Interim Final Rule, 84 Fed. Reg. 33,829 (effective July 16, 2019) (to be codified at 8 C.F.R. pt. 208, 1003, 1208); Memorandum from Jefferson B. Sessions, Attorney Gen., U.S. Dep't of Just., to Fed. Prosecutors Along the Southwest Border on Zero-Tolerance for Offenses Under 8 U.S.C. \& 1325(a) (Apr. 6, 2018), https:/perma.cc/S7PX-GFYS; William A. Kandel, Cong. Rsch. Serv., R45266, The Trump ADMINISTRATION'S “Zero TOLERANCE" IMMigration ENFORCEMENT POlicy (2021); Exec. Order No. 13,841, 83 Fed. Reg. 29,435, (June 20, 2018).

162. See Safe Third Country Interim Final Rule, 84 Fed. Reg.; Aliens Subject to a Bar on Entry Under Certain Presidential Proclamations: Procedures for Protection Claims, 83 Fed. Reg. 55,934, 55,934-35 (Nov. 9, 2018) (to be codified at 8 C.F.R. pt. 208, 1003, 1208).

163. See, e.g., Matter of A-B-, 27 I. \& N. Dec. 316 (A.G. 2018), abrogated by Grace v. Whitaker, 344 F. Supp. 3d 96 (D.D.C. 2018).

164. See, e.g., Final Rule U.S. Citizenship and Immigration Services Fee Schedule and Changes to Certain Other Immigration Benefit Request Requirements, 85 Fed. Reg. 46,788, (to be codified as 8 C.F. R. pt. $103,106,204,211,212,214,216,217,223,235,236,240,244,245,245 \mathrm{a}, 248,264,274 \mathrm{a}, 286$, 301, 319, 320, 322, 324, 334, 341, 343a, 343b, and 392); Final Rule Asylum Application, Interview, and Employment Authorization for Applicants, 85 Fed. Reg. 38,532 (to be codified as 8 C.F.R. pt. 208, 274a); see also David J. Bier, Immigration Form Denials Rise Every Quarter Except One Under Trump, Up $80 \%$ Overall, CATO InSTITUTE (May 15, 2019), https://perma.cc/K8BC-Z5KL.

165. See Harris, supra note 112 , at 150.

166. Procedures for Asylum and Withholding of Removal; Credible Fear and Reasonable Fear Review, 85 Fed. Reg. 36,264 (proposed June 15, 2020) (to be codified at 8 C.F.R. pt. 208, 235, 1003, $1208,1235)$. 
seven executive orders on immigration ${ }^{167}$ and directed DHS to undertake a 100 day moratorium on deportations for certain noncitizens. ${ }^{168}$ He has also drafted a bill, to be introduced by Senator Menendez, ${ }^{169}$ that would create a path to citizenship for the undocumented, among many other significant changes. ${ }^{170}$ Finally, he has ordered that there be no new enrollments in MPP, the protocols requiring Spanish-speaking asylum seekers to remain in Mexico. ${ }^{171}$ Of course, the tensions between managing the COVID-19 pandemic and what may be perceived as a "loosening" of immigration regulation and control may be politically fraught. Perhaps not surprisingly, Susan E. Rice, who is President Biden's pick for Director of the Domestic Policy Council, has said that the Biden administration will not immediately end the practice of rapidly expelling migrants to Mexico under Title $42 .{ }^{172}$ This Article argues not only that he should, but that he must. And further, that there are lessons to be learned from public health experts, courts, and examples abroad about alternative ways to manage migration and asylum in times of public health crisis.

\section{A. Title 42 Violates Our Domestic and International Legal Obligations}

In November 2020, the D.C. District Court issued a preliminary injunction in P.J.E.S. blocking the Trump administration from expelling unaccompanied immigrant children from the United States under Title $42 .{ }^{173}$ In so holding, the Court found that Section 265 likely does not authorize expulsions

167. Proclamation No. 10,141, Ending Discriminatory Bans on Entry to the United States, 86 Fed. Reg. 7005 (Jan. 20, 2021); Proclamation No. 10,142, Termination of Emergency With Respect to the Southern Border of the United States and Redirection of Funds Diverted to Border Wall Construction, 86 Fed. Reg. 7225 (Jan. 20, 2021); Exec. Order No. 13,993, Revision of Civil Immigration Enforcement Policies and Priorities, 86 Fed. Reg. 7051 (Jan. 20, 2021); Exec. Order No. 13,988, Preventing and Combating Discrimination on the Basis of Gender Identity or Sexual Orientation, 86 Fed. Reg. 7023 (Jan. 20, 2021); Exec. Order No. 13,986, Ensuring a Lawful and Accurate Enumeration and Apportionment Pursuant to the Decennial Census, 86 Fed. Reg. 7015 (Jan. 20, 2021); Memorandum on Preserving and Fortifying Deferred Action for Childhood Arrivals (DACA), 86 Fed. Reg. 7053 (Jan. 20, 2021); Memorandum on Reinstating Deferred Enforced Departure for Liberians, 86 Fed. Reg. 7055 (Jan. 20, 2021).

168. Memorandum from David Pekoske, Acting Sec'y of U.S. Dep't of Homeland Sec., to Troy Miller, Senior Off. Performing the Duties of the Comm'r, U.S. Customs and Border Prot., Tae Johnson, Acting Dir., I.C.E. \& Tracey Renaud, Senior Off. Performing the Duties of the Dir., U.S.C.I.S., on Review of and Interim Revision to Civil Immigration Enforcement and Removal Policies and Priorities (Jan. 20, 2021), https://perma.cc/3F4R-DJPP. But see Texas v. United States, 515 F. Supp. 3d 627, 63839 (S.D. Tex. 2021) (issuing a nationwide temporary restraining order enjoining the Biden administration from implementing the 100-day moratorium on deportations).

169. Press Release, U.S. Sen. Bob Menendez, Menendez to Lead Biden-Harris Immigration Legislation in the Senate (Jan. 20, 2021), https://perma.cc/S6CP-489S.

170. See Nick Miroff \& Maria Sachetti, Biden Says He'll Reverse Trump Immigration Policies but Wants 'Guardrails' First, WASH. POST (Dec. 22, 2020), https://perma.cc/7ULK-THCT.

171. DHS Statement on the Suspension of New Enrollments in the Migrant Protection Protocols Program, U.S. DeP'T OF Homeland SEC. (Jan. 20, 2021), https://perma.cc/E53U-8XBY.

172. See id:; see also Miroff and Sachetti, supra note 170.

173. P.J.E.S. v. Wolf, 502 F. Supp. 3d 492, 551 (D.D.C. 2020). But see Dorothy Atkins, Feds Admit to Expelling 34 Migrant Kids Despite Injunction, LAw360 (Dec. 14, 2020, 4:52 PM), https://perma.cc/ $62 \mathrm{YU}-\mathrm{YQBX}$ (noting that the government admitted to expelling 34 immigrant children despite the District Court's issuance of a preliminary injunction). 
because, simply put, when the government wishes to grant the power to expel, it "does so plainly." 174 Section 265 neither uses the word "expel" nor any synonym. The Court also found that, given the statutory scheme of Section 265 and related statutes ${ }^{175}$-referred to collectively as "quarantine laws"- the government's power is limited to the power to quarantine and contain, and not the power to expel.

\section{B. We Must Heed the Advice of Public Health Experts}

Senior experts within the CDC have protested the Title 42 ban from the beginning. In early March, the agency's Division of Migration and Quarantine, led by Dr. Martin Cetron, refused to support the order because there was no adequate public health basis for such a drastic move, according to three people with knowledge of his decision. ${ }^{176}$ Subsequent pressure from HHS and DHS still did not sway senior scientists within the CDC, who were ultimately pressured into acting when Vice President Pence and DHS Secretary Chad Wolf became involved. ${ }^{177}$ But resistance to political pressure from the White House remained strong. ${ }^{178}$ Fortunately, public health experts and lessons learned from abroad can provide alternate ways forward.

\section{Dispatch Additional Resources to the Border to Process Migrants Quickly}

President Biden must repeal the Title 42 Process and dispatch additional resources, including asylum officers and humanitarian aid workers, to the border to process asylum seekers expeditiously. This is not an insurmountable challenge. A 100 -day moratorium on deportations, ${ }^{179}$ as well as a halt to further border wall construction, frees up resources to be redirected elsewhere. Indeed, in his executive order on January 20, 2021, President Biden contemplated a redirection of border wall funds and directed DHS, along with other agencies, to determine how and where this money is spent. ${ }^{180}$

Marshalling this kind of additional support at the border is not unprecedented. In times of crisis, the United States has previously directed additional

174. P.J.E.S., 502 F. Supp. 3d at 538.

175. E.g., Quarantine stations, grounds, and anchorages, 42 U.S.C. $\$ 267$; Quarantine duties of consular and other officers, 42 U.S.C. $\$ 268$; Quarantine regulations governing civil air navigation and civil air navigation and civil aircraft, 42 U.S.C. $\$ 270$; Penalties for violation of quarantine laws, 42 U.S.C. $\S$ 271; Administration of oaths by quarantine officers, 42 U.S.C. $\$ 272$.

176. See Jason Dearen \& Garance Burke, Pence Ordered Borders Closed After CDC Experts Refused, AP NEwS (Oct. 3, 2020), https://perma.cc/CJ4L-R7BA.

177. See id.

178. Graeme Massie, More Than 1,000 Current and Former CDC Staff Hit Out at Trump Coronavirus Response, INDEPENDENT (Oct. 18, 2020, 9:06 AM), https://perma.cc/WY58-S6N3.

179. Note, however, that the Biden administration's implementation of the 100-day moratorium on deportations has been halted by the issuance of a nationwide temporary restraining order. See Texas v. United States, 515 F. Supp. 3d 627, 639 (S.D. Tex. 2021).

180. Proclamation No. 10,142, 86 Fed. Reg. 7225 (Jan. 20, 2021). 
support, resources, and funds toward refugees and asylum seekers. ${ }^{181}$ As of August 2021, the Biden administration had floated a proposal to dispatch additional asylum officers to the border. ${ }^{182}$ This is a positive step, though advocates fear that it will also fast track removals of unrepresented asylum seekers, rushed to present claims pro se. The impact of this proposal remains to be seen, though if implemented successfully, it could lessen the burden on the border while also ensuring that asylum seekers at the border are not added to the already long list of asylum seekers waiting for their cases to be heard within the United States. ${ }^{183}$ Additional resources, rather than going to increased detention, should be directed toward legal services for these asylum seekers, so that their claims may be fairly adjudicated, consistent with President Biden's immigration platform. ${ }^{184}$

\section{End Reliance on Detention and Congregate Settings and Promote Family Unity}

In Mexico, more than 65,000 migrants and asylum seekers have been enrolled in MPP, and thousands of them now live in overcrowded, makeshift refugee camps with limited resources for income, food, and sanitation. ${ }^{185}$ Congregate settings like refugee camps, whether makeshift or long-established, as well as detention centers, ${ }^{186}$ are often a source for the spread of illness. The Trump administration protested the number of incoming asylum seekers by saying that there was no room to hold them in already crowded detention centers. Fortunately, we have more options than either allowing asylum seekers to languish in camps in Mexico or detaining them in the United States.

Alongside the deployment of additional asylum officers to the border should come a preference for release over detention. ${ }^{187}$ Indeed, the COVID-

181. Press Release, U.S. Dep't of Homeland Sec., DHS Update on the Situation Along the Southwest Border (Aug. 7, 2014), https://perma.cc/9ZAS-B2SR; see also Mark Felsenthal, U.S. Administration Transferring \$405 Million for Border Operations, REUTERS (Aug. 1, 2014), https://perma. cc/7ACY-6GUR.

182. Ted Hesson, U.S. Plans to Double Number of Asylum Officers in Biden Border Overhaul, REUTERS (Aug. 18, 2021, 11:31 AM), https://perma.cc/586H-AY9W.

183. See Immigration Court Backlog Tool: Pending Cases and Length of Wait by Nationality, State, Court, and Hearing Location, TRAC IMMIGRATION, https://perma.cc/SG94-RSDA (last updated Dec. 2020) (reporting that there are over 1.2 million cases currently pending in the Immigration Courts with an average wait time of 869 days for a hearing).

184. The Biden Plan for Securing Our Values as a Nation of Immigrants, BIDEN-HARRIS, https:// perma.cc/9LV4-PXJR.

185. Hum. RTs. Watch, "Like I'm Drowning": Children and Families Sent to HaRm By the US 'Remain in MeXico' Program 4 (2021), https://perma.cc/82FQ-XJFS; see also Caitlin Dickerson, Inside the Refugee Camp on America's Doorstep, N.Y. TIMES (Oct. 23, 2020), https://perma.cc/U7DM$6 \mathrm{YBW}$.

186. See, e.g., John Washington, ICE Mismanagement Created Coronavirus "Hotbeds of Infection" In and Around Detention Centers, INTERCEPT (Dec. 9, 2020, 1:00 PM), https://perma.cc/PX9S-25JF; Jerod MacDonald-Evoy, How COVID-19 Spread Through Neighboring ICE Detention Facilities in Eloy, AZ MirRor (Nov. 16, 2020, 2:02 PM), https://perma.cc/YA2A-CPKL.

187. This is not unprecedented. From the closing of Ellis Island in 1954 until the mid-1980s, release was essentially the presumption, and the INS routinely acted under a portion of the INA authorizing the 
19 pandemic has shown us that relying less on immigration detention is possible. While ICE typically holds approximately 45,000 persons in immigration custody on any given day, by the end of 2020 , as the pandemic was spiking, that number dropped to just $20,000 .{ }^{188}$ There are no documented negative impacts of this reduction, and no reason we cannot continue to rely less on detention. ${ }^{189}$

In the first instance, we should promote family reunification. A study by the US Immigration Policy Center at the University of California-San Diego found that of 607 asylum seekers in the MPP program in Mexico in 2019, 92 percent had family with whom to reunite in the United States. ${ }^{190}$ Once processed through a port of entry, or along the border, asylum seekers should be permitted to reunite with family members within the United States. For those who cannot reunite with family, we can learn lessons from the COVID-19 pandemic. Crisis is the birthplace of creativity, and cities and states have employed many creative options to safely house service/front line workers and the homeless over the last year. These alternatives include vacant hotel rooms, dorm rooms, and subsidized apartments. ${ }^{191}$

In the event that there are concerns raised about noncitizens failing to appear for their hearings, we can look toward the Obama-era Family Case Management Program ("FCMP"). ${ }^{192}$ The FCMP provided legal and social services support to noncitizen families facing removal from the United States. ${ }^{193}$ Though the program had downsides, namely that it was overseen by GEOCares, a GEO Group subsidiary known for running private prisons, ${ }^{194}$ the program also had a 99 percent compliance rate with ICE and immigration court requirements at a fraction of the cost of detention and "supported

Attorney General to parole noncitizens seeking admission to the United States for "reasons deemed strictly in the public interest." See Jonathan Simon, Refugees in a Carceral Age: The Rebirth of Immigration Prisons in the United States, 10 PuB. CulturE 577, 581 (1998).

188. ICE details COVID-19 Impacts on Immigration Enforcement in FY 2020, U.S. IMMIGR. AND CuSTOMS ENF'T, https://perma.cc/6C5T-3M2K (last updated Mar. 1, 2021).

189. See César Cuauhtémoc García Hernández, Abolishing Immigration Prisons, 97 B.U.L. Rev. 245, 248, 257 (2017) (noting that "the United States did not lock up migrants for migration-related activities for much of the twentieth century" and that most empirical evidence tends to discredit "the proposition, voiced tirelessly by prominent politicians in recent years, that migrants are disproportionately prone to criminal activity").

190. Tom K. Wong \& Vanessa Ceceña, U.S. Immigr. Pol'y Ctr., UC San Diego, Seeking ASYLUM: PART 2, at 3, 13 (2019), https://perma.cc/5CD8-5Q6Q.

191. See C.J. Hughes, Pummeled by the Pandemic, Hotel Owners Get Creative With Their Space, N. Y. TIMES (Oct. 6, 2020), https://perma.cc/4F5S-HD5G; Jim Shelton, Yale Readies Hundreds of Rooms for Medical Personnel, First Responders, YALENEws (Apr. 3, 2020), https://perma.cc/8AQA-EGDF.

192. See Ruthie Epstein, The Triedand-True Alternatives to Detaining Immigrant Families, ACLU (June 22, 2018, 4:30 PM), https://perma.cc/H3DQ-KSX7 (The FCMP was "run by Immigration and Customs Enforcement ... as an alternative to detention for families seeking asylum.").

193. Id. (The FCMP "provided case management, referrals for support services, and legal orientation, in partnership with community-based non-governmental organizations, in order to make sure that vulnerable families' most urgent needs were met and they had the information they needed to comply with legal obligations.").

194. See Women's Refugee Commission, The Family Case Management Program: Why Case Management Can and Must Be Part of the U.S. Approach to Immigration 4-5 (2019), https:// perma.cc/2273-8FRE; see also. Harris, supra note 112. 
hundreds of families in finding stability in their communities, supporting them with their immigration requirements, and beginning to prepare them for the outcomes of their case." ${ }^{\prime 195}$ The program, which cost between $\$ 36-\$ 38$ per day, rather than $\$ 800$ per day to detain a family with 2.5 members, ${ }^{196}$ was cancelled by President Trump, ${ }^{197}$ but can and should be reimagined. Under the Biden administration, an improved program could encourage enrollment and provide legal and social services support. It could be overseen not by a private prison subsidiary, but by an experienced refugee service provider. ${ }^{198}$ Such a program is not only the right thing to do but also provides immense cost savings for the government, and in the time of a public health crisis, keeps countless families out of congregate settings where the virus can easily spread.

\section{CONCLUSION}

The Title 42 Process expels would-be asylum seekers under the guise of protecting public health. In so doing, it disproportionately impacts Central American asylum seekers in a pattern consistent with historical racism against the region. Not only do these expulsions run counter to the recommendations of public health experts, but they violate our domestic and international legal obligations. Fortunately, there are alternatives. The Biden administration previously promised to address some of the worst Trump administration immigration policies; Title 42 should be high on the list. Doing so will save lives and begin to repair an insidious legacy of racism that uses public health as a proxy.

195. WOMEN's REFUGEE COMMISSION, supra note 194, at $1,14$.

196. Id. at 8

197. See Jane C. Timm, This Obama-era Pilot Program Kept Asylum-Seeking Migrant Families Together. Trump Canceled It, NBC NEws (June 24, 2018, 8:54 AM), https://perma.cc/XS9H-TSAG.

198. See Harris, supra note 112 , at 137. 
